\title{
LEARNING STRATEGIES AND MOTIVATIONAL PATTERNS IN DEGREE OF THE SCHOOL OF ECONOMIC AND BUSINESS
}

\author{
Ana Salomé García Muñiz \\ Assist. Prof. Dr., University of Oviedo, Spain, asgarcia@uniovi.es
}

\begin{abstract}
In this study the main purpose is to explore relations between students' learning strategies and their motivational patterns in the course Introduction to Economic Statistics of University of Oviedo. The course Introduction to Economic Statistics is a basic training in a Business Administration degree. It is a common course for the degrees in Economics, Accounting and Finance and Labour Relations and Human Resources, which are also part of the course catalogue of the School of Economics and Business. The course has no prerequisites. It is recommended that the student should be competent in mathematics, in any of its options at secondary (high school) level. The evaluation of the course is based on continuous assessment throughout the course and final exam. The results of final grades are very different between the four degrees. In this study, the differences between the learning and motivational patterns employed by the students of the degrees are analyzed. The correlations of motivation and learning strategies with final grades and/or continuous assessment are exposed. The data were collected thorough the Learning Strategies and Motivation Questionnaire. Participants were 169 undergraduates. The results about the disparities between grades could be useful to correct teaching practices and evaluation performances in some grades.
\end{abstract}

Keywords: Motivation, Learning strategies, Higher education, Statistics.

\section{INTRODUCTION}

The course Introduction to Economic Statistics is a basic training in a Business Administration degree. It is a course common to the degrees in Economics, Accounting and Finance and Labour Relations and Human Resources, which are also part of the course catalog of the School of Economics and Business at University of Oviedo (Spain).

From an educational perspective, two reasons can be highlighted in order to justify the teaching of statistics at the undergraduate level: statistics are useful for a future career in economics-business and knowledge of statistics as a part of general education is desirable for all citizens. In this context, the course in statistics in 
the first undergraduate year, aims to introduce students to statistical reasoning, providing basic training to enable them to apply different analytical tools to economic and social problems. This training will be supplemented with compulsory and optional courses in later years. The course has no prerequisites. It is recommended that the student should be competent in mathematics, in any of its options, at secondary (high school) level. The contents, teaching methodology and assessment of the course are the same for the four degrees. The program is divided into lessons that correspond to weekly teaching units. The face-to-face teaching is based on two types of activities: lectures and classroom practices. These activities are complemented by practical sessions in the computer lab. The evaluation of the course is based on a continuous assessment and a final exam. The continuous assessment values the effort and the work of the student during the course by means of different types of individual activities. The final exam assesses the knowledge and the capabilities to apply the statistical tools.

However, the academic outcomes of this course have been different between the degrees along the years. "The absence of an achievement in this field by students of social science, behavioral science or education, among others, is a recurring topic that teachers and researchers have highlighted in a diverse cultural context for more than 30 years" (García-Santillán et al., 2016).

The students' attitude has been pointed out as a key in the process of teaching-learning in the Statistics subjects (Mondéjar et al., 2008; Mondéjar \& Vargas 2010, among others). According to various authors (Alonso Tapia, 1999; Covinton, 2000; Rinaudo et al., 2003), interest and effort on the subjects depends basically on three factors: utility of learning concepts, possibilities of surpassing the subject and the cost in terms of time and effort that it will involve. Furthermore, several factors related with context and/or the student can be key to the adoption of a deeper approach to learning in student-centered learning environments. Baeten et al. (2010) review the recent literature and detail the factors collected in the figure 1.

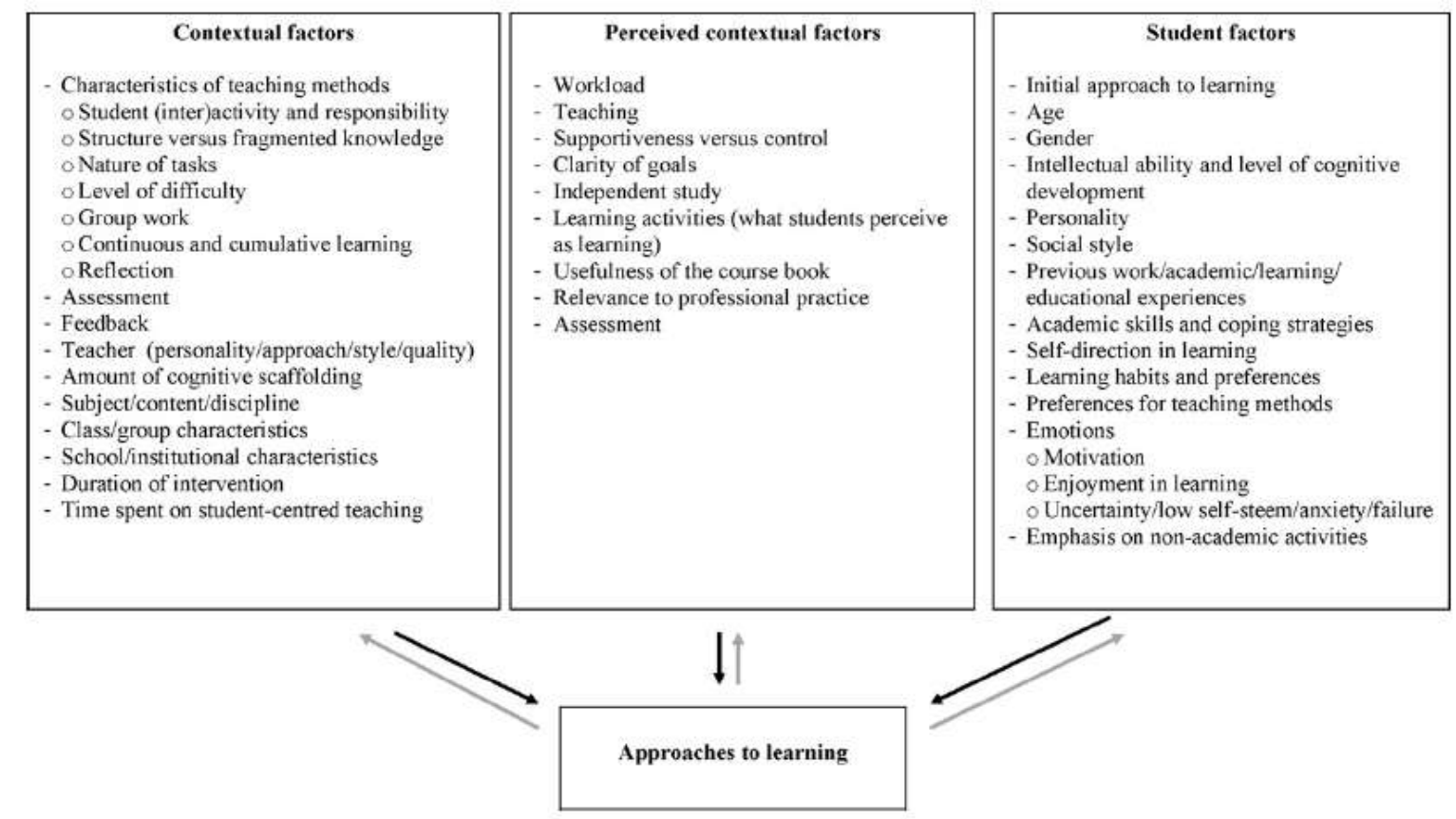

Fig. 1. Approaches to learning. Source: Baeten et al. (2010).

Usually, questionnaires have been used for measurement the attitude toward Statistics (Blanco, 2008; Carmona, 2004) as: Statistics Attitudes Survey (Roberts \& Bilderback 1980), Attitudes Toward Statistics (Wise 1985), Statistics Attitude Inventory (Zeidner 1991), Attitude Toward Statistics (Miller et al., 2007), Survey of Attitudes Toward Statistics (Schau et al., 1995), Quantitative Attitudes Questionnaire (Chang 1996) or some Spanish surveys (Auzmendi, 1992, Mondéjar et al. 2008, Estrada et al., 2004). Nevertheless, Shaughnessy (2007) or Eichler \& Zapata-Cardona (2016), among others, point out the need to expand empirical research on motivation, strategies and attitudes towards statistics. In this work, the Motivated Strategies for Learning Questionnaire (MSLQ), developed by a team of researchers from the National Center for Research to Improve Postsecondary Teaching and Learning (NCRIFFAL) and the School of Education at the University of Michigan (McKeachie et al., 1986; Pintrich et al., 1991) is used to study the learning 
strategies and motivational patterns of the course Introduction to Economic Statistics in Business Administration, Economics, Accounting and Finance and Labour Relations and Human Resources degrees at University of Oviedo. This questionnaire can be applied to assess not only students' motivation, but some of factors key in the approaches to learning detailed by Baeten et al. (2010). The motivation and learning strategies items are correlated with final grades.

\section{METHODOLOGY}

The MSLQ is a 81-item questionnaire founded on a cognitive view of motivation and learning strategies (McKeachie et al., 1986; Pintrich et al., 1991; Pintrich \& DeGroot, 1990). Under this scope, the student's motivation and learning strategies is not the same in all the courses. The nature, interest of course or the efficacy for performing, among other can affect the social-cognitive view of the student. Students rate themselves on a 7-point Likert scale, from 1 (not at all true of me) to 7 (very true of me).

The English version has been adapted to the Spanish framework in the called "Cuestionario de Estrategias de Aprendizaje y Motivación- CEAM" (Roces, Tourón \& González-Torres, 1995).

The used version of this study consists of 26 items which are exposed next. Some items of the MSLQ questionnaire have been excluded for lack of interest in the sample and the course.

\section{Motivation scale}

Task Value Sub-scale

- Item 4. I think I will be able to use what I learn in this course in other courses.

- Item 10. It is important for me to learn the course material in this class.

- Item 17. I am very interested in the content area of this course.

- Item 23. I think the course material in this class is useful for me to learn.

- Item 26. I like the subject matter of this course.

- Item 27. Understanding the subject matter of this course is very important to me.

\section{Self-Efficacy for Learning \& Performance Sub-scale}

- Item 5. I believe I will receive an excellent grade in this class.

- Item 12. I'm confident I can learn the basic concepts taught in this course.

- Item 6. I'm certain I can understand the most difficult material presented in the readings for this course.

- Item 15. I'm confident I can understand the most complex material presented by the instructor in this course.

- Item 20. I'm confident I can do an excellent job on the assignments and tests in this course.

- Item 21. I expect to do well in this class.

- Item 29. I'm certain I can master the skills being taught in this class.

- Item 31. Considering the difficulty of this course, the teacher, and my skills, I think I will do well in this class.

\section{Learning strategies scales}

\section{Time/Study Environmental Management Sub-scale}

- Item 70. I make sure that I keep up with the weekly readings and assignments for this course.

- Item 73. I attend this class regularly.

- Item 43. I make good use of my study time for this course.

- Item 34. When studying for this course, I often try to explain the material to a classmate or friend.

Peer Learning Sub-scale 
- Item 45. I try to work with other students from this class to complete the course assignments Item 50. When studying for this course, I often set aside time to discuss course material with a group of students from the class.

\section{Help Seeking Sub-scale}

- Item 58. I ask the instructor to clarify concepts I don't understand well.

- Item 68. When I can't understand the material in this course, I ask another student in this class for help.

- Item 75. I try to identify students in this class whom I can ask for help if necessary.

\section{RESULTS}

Historically, the learning outcomes vary greatly between degrees. The next figure presents the success rate in the course since the beginning of the degrees in the Bologna process. The success rate is calculated as the ratio between number of passing students and presented students. Economics shows the highest rates in contrast with Labour Relations and Human Resources.

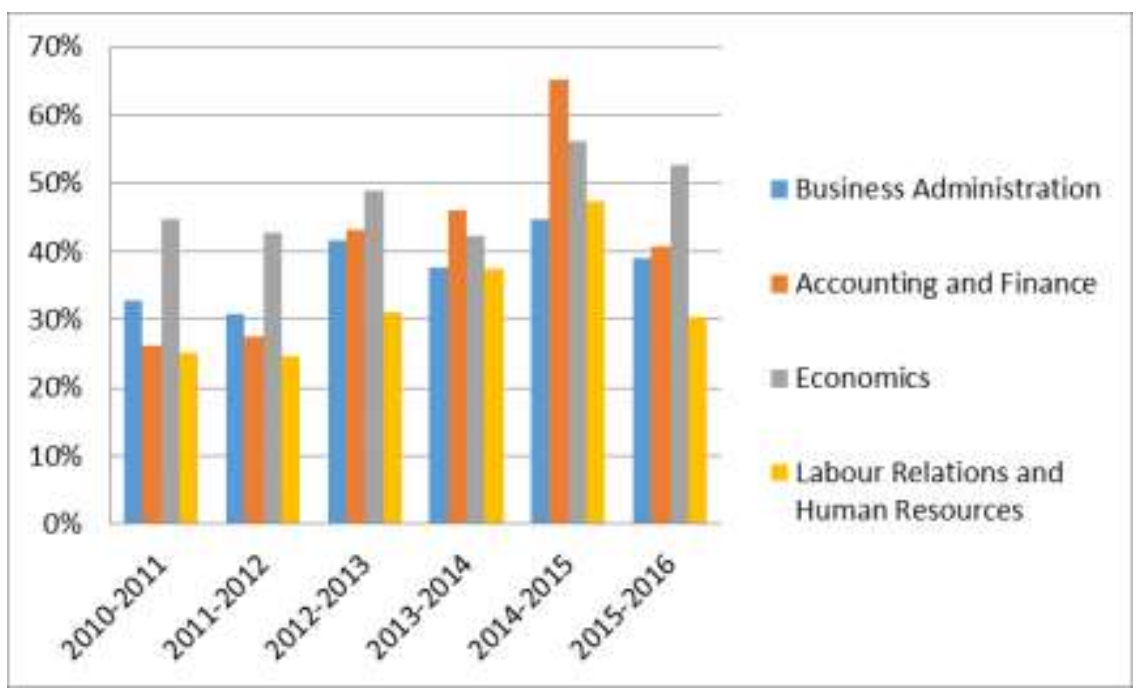

Fig. 2. Success rate. Source: Own elaboration.

The results of MSLQ can provide an empirical linkage between the individual differences in motivation and/or learning strategies with academic performance. The MSLQ was inserted as Online Questionnaire in Virtual Campus of the University of Oviedo at the end of the quarter. The sample was 168 students of School of Economics and Business at University of Oviedo. There were 62 Business Administration students, 46 Economics students, 28 Accounting and Finance students and 32 Labour Relations and Human Resources students.

With the aim of analysis the reliability and validity of MSLQ, alfa and confirmatory factor analysis are used. Cronbach's alpha is a frequently employed index of test reliability or internal consistency. Alpha is a measure to evaluate the extent to which multiple-item determine a concept or construct. Its values are between 0 and 1. In this study, the used instrument has a reliability of 0.889 (Cronbach's $\alpha=0,889$ ) in the motivation area, all items contributed adequately to this reliability. In the learning strategies area, the reliability is minor, but acceptable (Cronbach's $\alpha=0,711$ ). The Cronbach-alpha values are robust and similar to other studies using also this instrument as Pintrich et al., 1991 or Roces et al., 1995, among others.

The factor analysis requires at least five observations per variable in order to make an adequate and reliability study (Hair et al., 1998). Given the sample size, a confirmatory factor analysis is not completed for each degree. One confirmatory factor analysis is done for the set of motivational items and another for the set of learning strategies items. Previously, the Bartlett's sphericity test and the KMO index are applied. Bartlett's test of sphericity tests whether the correlation matrix is an identity matrix, which would show that the factor model is inappropriate. KMO is based on the comparison of the elements of the matrix correlation with the partial correlation coefficients. KMO returns values between 0 and 1 . KMO values between 0.8 and 
1 indicate the sampling is adequate for factor analysis. KMO values between 0.60 to 0.8 are middling sampling adequacy for factor analysis. In table 1 the results of these tests are exposed.

Table 1. Bartlett's sphericity test and the KMO index

\begin{tabular}{|c|c|c|}
\hline & Motivation & Learning strategies \\
\hline Kaiser-Meyer-Olkin Measure of Sampling Adequacy & 0.850 & 0.670 \\
\hline $\begin{array}{r}\text { Approx Chi-Square } \\
\text { df } \\
\text { Sig }\end{array}$ & $\begin{array}{c}1212.039 \\
91 \\
0.000\end{array}$ & $\begin{array}{c}359.390 \\
36 \\
0.000\end{array}$ \\
\hline
\end{tabular}

The correlation between the variables is checked and therefore, the factor analysis application is justified. The motivation data present a meritorious adequacy, but the learning items adequacy is middling.

The table 2 present the rotated component matrix obtained from the factor analysis.

Table 2. Rotated Component Matrix

\begin{tabular}{|l|r|r|}
\hline & \multicolumn{2}{|c|}{ Component } \\
\hline & Performance & Task \\
\hline IT20 & .859 & .082 \\
\hline IT31 & .842 & .024 \\
\hline IT29 & .798 & .278 \\
\hline IT5 & .743 & .032 \\
\hline IT12 & .661 & .283 \\
\hline IT15 & .637 & .248 \\
\hline IT6 & .627 & .319 \\
\hline IT26 & .621 & .342 \\
\hline IT17 & .498 & .364 \\
\hline IT10 & .220 & .832 \\
\hline IT23 & .335 & .791 \\
\hline IT4 & .133 & .752 \\
\hline IT27 & .020 & .622 \\
\hline IT21 & .298 & .317 \\
\hline
\end{tabular}

\begin{tabular}{|l|r|r|r|}
\hline \multirow{2}{*}{} & \multicolumn{3}{|c|}{ Component } \\
\cline { 2 - 4 } & \multicolumn{1}{|c|}{ Time } & \multicolumn{1}{c|}{ Help } & \multicolumn{1}{c|}{ Peer } \\
\hline IT70 & .803 & -.019 & .097 \\
\hline IT43 & .740 & .007 & .053 \\
\hline IT73 & .675 & .255 & -.078 \\
\hline IT58 & .617 & -.035 & .155 \\
\hline IT75 & .021 & .843 & -.053 \\
\hline IT68 & -.058 & .797 & .333 \\
\hline IT50 & .248 & .664 & .412 \\
\hline IT45 & .039 & .184 & .846 \\
\hline IT34 & .121 & .111 & .786 \\
\hline
\end{tabular}

Source: Own elaboration.

The obtained factors are very similar to the sub-scales proposed by Pintrich et al. (1993). Only the items: 26, 17, 21, 58 and 50 are located in other sub-scales in relation to Pintrich et al. (1993). In motivational scales, the items 26 and 17 appear in task value sub-scale and item 21 is in self efficacy for learning and performance sub-scale. In cognitive strategy scale, the items 58 and 50 are placed in help seeking sub-scale and peer learning sub-scale, respectively.

The MSLQ sub-scales are correlated with student's final course grades. All the correlations are presented in the annex. Only Self-Efficacy for Learning \& Performance aspects (0.259) and Time or Study Environmental Management $(0.180)$ have a significant correlation with final grade. Values of correlation are indicated in parentheses. Differences between the grades are observed. Final mark presents a significant positive correlation with factors related to the time study management (0.250) in Business and Administration degree. In Economics degree, the factors correlated with the final mark are the Self-Efficacy for Learning \& Performance (0.296) strategies and the help of others (0.336). However, the performance is the only factor with a significant correlation with final marks in Accounting and Finance degree (0.442). No significant correlation with final mark is present in the Labour Relations and Human Resources degree.

These results point out not common motivational patterns for learning in the four degrees. The nonparametric Kruskal- Wallis test can be used for comparing the samples of the four degrees and detect whether there is a difference in data. Kruskal-Wallis test is a non-parametric test. It doesn't rely on assumptions as a normal distribution in the population or equal variance across groups. It is a test on the equity of medians from two or more populations. The median is largely unaffected by outliers or skewed data 
The next table presents the items in which there is evidence that the medians of the four grades are not equal and so the motivation or learning strategies of the selected items are not the same in the four degrees.

Table 3. Kruskal- Wallis test

\begin{tabular}{|r|r|r|r|r|r|r|r|r|r|r|r|r|r|r|r|}
\hline & IT4 & IT10 & IT17 & IT23 & IT26 & IT27 & IT5 & IT12 & IT6 & IT15 & IT20 & IT29 & IT31 & IT70 & IT73 \\
\hline $\begin{array}{r}\text { Chi- } \\
\text { squared }\end{array}$ & 30.892 & 38.039 & 7.891 & 20.274 & 10.135 & 7.010 & 7.474 & 11.700 & 27.235 & 33.508 & 13.221 & 16.716 & 9.796 & 8.957 & 8.059 \\
\hline Df & 3 & 3 & 3 & 3 & 3 & 3 & 3 & 3 & 3 & 3 & 3 & 3 & 3 & 3 & 3 \\
\hline $\begin{array}{r}\text { Asymp. } \\
\text { Sig }\end{array}$ & .000 & .000 & .048 & .000 & .017 & .072 & .058 & .008 & .000 & .000 & .004 & .001 & .020 & .030 & .045 \\
\hline
\end{tabular}

Source: Own elaboration.

The differences are in the management of the regularity in the adopted learning strategies (Item 70, Item 73), but above all are concentrated in the value of the subject (Item 4, Item 10, Item 17, Item 23, Item 26, Item 27) and the expectative about the possible performance in the subject (Item 5, Item 6, Item 12, Item 15, Item 20 , Item 29, Item 31). Several post hoc tests should be done to determine where any differences lie between the four degrees.

The figure 3 reports $95 \%$ confidence intervals for the mean of the previous items as a first approximation to detect the differences between degrees in these items descriptively. The numbers associated to the grade in the X-axis represent the degrees: Business Administration (1), Accounting and Finance (2), Economics (3), and Labour Relations and Human Resources (4). In Labour Relations and Human Resources, the values attached to "Introduction to Economic Statistics" course (IT4, IT10, IT17, IT23, IT26, IT27) and the expectatives about self-efficacy for learning and possible performance (IT5, IT6, IT12, IT15, IT20, IT29, IT31) are smaller than for the rest of the degrees. Even though, Labour Relations and Human Resources students step up efforts to management their study time by attending the class regularly (IT73) and keeping up the weekly course tasks (IT70) more intensively. In contrast, Accounting and Finance students retreat from the tasks more usually. Furthermore, Labour Relations and Human Resources and Accounting and Finance students assign lesser value to the learning of the Statistics concepts. Recommendations about new teaching tools to transform perceived ability and student valuing should be done in these two last degrees.

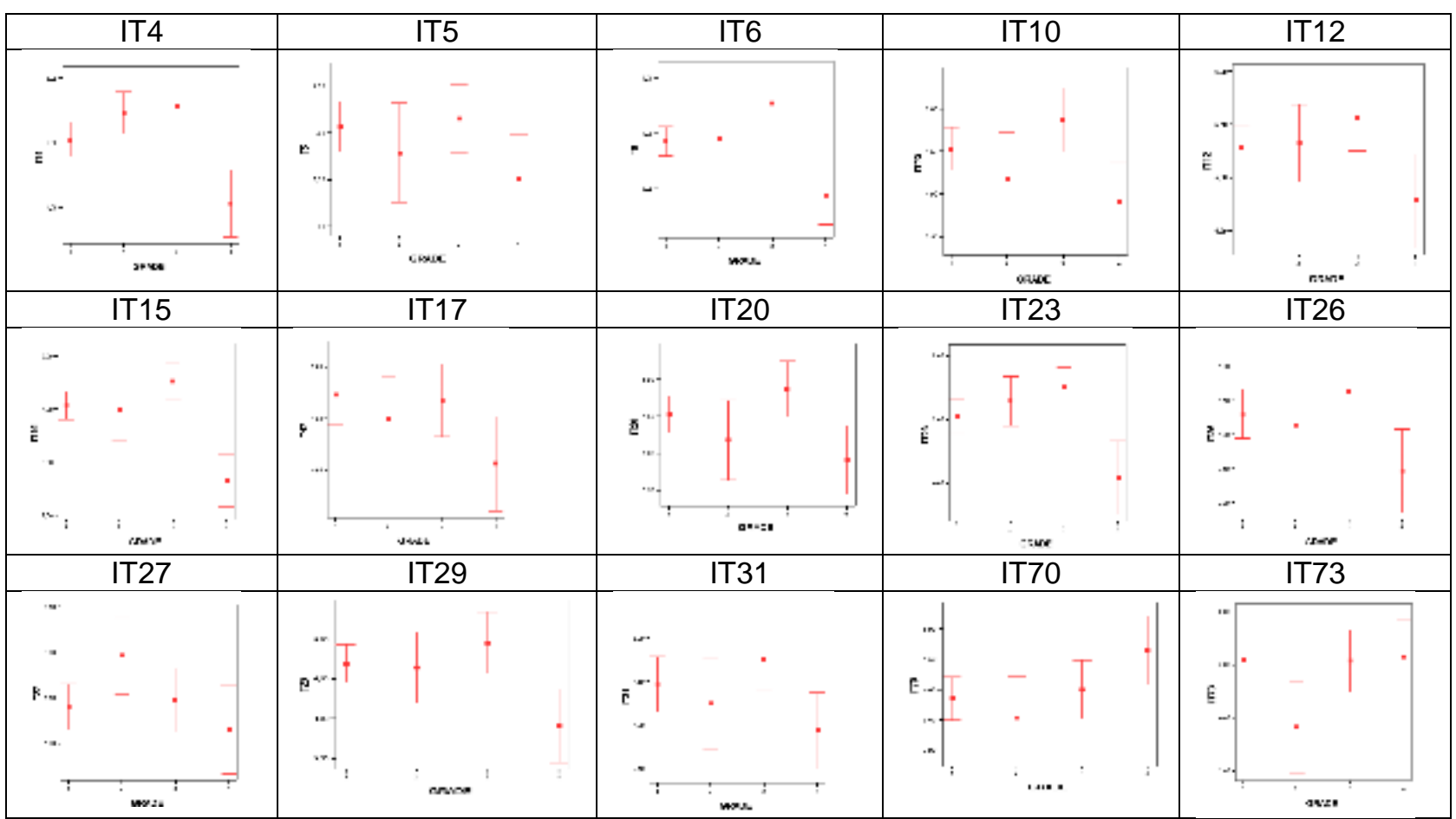

Fig. 3. Error Bar. Source: Own elaboration. 


\section{CONCLUSIONS}

This study examines the linkages between motivation, learning strategies and classroom academic performance for 168 students of the first Statistic course in the Faculty of Economics and Business of University of Oviedo. The subject Introduction to Economic Statistics is a common course to the degrees in Economics, Accounting and Finance and Labour Relations and Human Resources. The contents, teaching methodology and assessment of the course are the same for the four degrees.

The results obtain from the MSLQ point out a different cognitive view of motivation in the degrees. In general, the learning strategies are more stable between degrees with the exception of regularity in the assignments and assistant in the class. In Economics degree and Accounting and Finance degree, the motivation for learning has a significant impact in the mark of the subject. Not significant correlation between motivation and final mark is observed in Business and Administration degree and Labour Relations and Human Resources degree. The learning strategies around the time study management present a positive repercussion in the final mark only in Business and Administration. The observed attitudes are reported usually in the literature and as consequence a decrease of the interest in the Statistics course and thus a limitation in the quantitative training is produced (García-Santillán et al., 2016, Eichler and Zapata-Cardona, 2016).

In this sense, the perceived contextual factors to learning should be considered and adapted to each degree to get improved in academic results of the students. It might be advisable to reflect on this point that this requires a break in the common content and teaching framework in the four degrees. In Labour Relations and Human Resources degree, it is needed to make further efforts in order to create an environment conducive to increase attached value of the Statistics and the expectative about self-efficacy for learning. The value of Statistics for Accounting and Finance students should also be increased. A clear application of the Statistics in their respective professional field can enhance their perception about the topic and their attached value (Vanhoof et al., 2006).

A future question of research refers to the change in these students' motivation and learning strategies along the different years of the degrees. The literature reports mixed results between improvements in attitudes (Bond, Perkins, \& Ramirez, 2012; Chiesi \& Primi, 2010) and not changes (Schau and Emmioglu, 2012) although the individual variability can be large (Millar and White, 2014).

\section{ANNEX}

Table A1. Correlations

\begin{tabular}{|c|c|c|c|c|c|c|}
\hline & Performance & Task & Time & Help & Peer & Final mark \\
\hline \multirow[t]{2}{*}{ Performance } & 1 & .000 & $.274\left(^{\star *}\right)$ & .084 & .032 & $.259\left(^{* *}\right)$ \\
\hline & & $(1.000)$ & $(.000)$ & $(.280)$ & $(.678)$ & $(.001)$ \\
\hline \multirow[t]{2}{*}{ Task } & .000 & 1 & .009 & .087 & $-.158\left(^{*}\right)$ & .073 \\
\hline & $(1.000)$ & & (.912) & (.261) & $(.041)$ & $(.349)$ \\
\hline \multirow[t]{2}{*}{ Time } & $.274\left(^{\star \star}\right)$ & .009 & 1 & .000 & .000 & $\left..1800^{*}\right)$ \\
\hline & $(.000)$ & $(.912)$ & & $(1.000)$ & $(1.000)$ & $(.020)$ \\
\hline \multirow[t]{2}{*}{ Help } & .084 & .087 & .000 & 1 & .000 & .019 \\
\hline & $(.280)$ & (.261) & $(1.000)$ & & $(1.000)$ & $(.808)$ \\
\hline \multirow[t]{2}{*}{ Peer } & .032 & $-.158\left(^{*}\right)$ & .000 & .000 & 1 & -.049 \\
\hline & $(.678)$ & $(.041)$ & $(1.000)$ & $(1.000)$ & & $(.531)$ \\
\hline \multirow[t]{2}{*}{ Final mark } & $.259\left(^{\star \star *}\right)$ & .073 & $.180\left(^{*}\right)$ & .019 & -.049 & 1 \\
\hline & $(.001)$ & (.349) & $(.020)$ & $(.808)$ & $(.531)$ & \\
\hline
\end{tabular}

Source: Own elaboration.

${ }^{*}$ and ${ }^{* *}$ indicate, respectively, that the correlation is significant at the 0.05 and 0.01 levels (2-tailed).

Table A2. Correlations by degrees: Business and Administration and Economics

\begin{tabular}{|l|r|r|r|r|r|r|}
\hline & Performance & Task & Time & \multicolumn{1}{|c|}{ Help } & \multicolumn{1}{c|}{ Peer } & Final mark \\
\hline Performance & 1 & -.038 & $.255\left(^{*}\right)$ & -.065 & -.188 & .205 \\
\hline
\end{tabular}


IJAEDU- International E-Journal of Advances in Education, Vol. 3, Issue 8, August 2017

\begin{tabular}{|l|r|r|r|r|r|r|}
\hline & & $(.769)$ & $(.045)$ & $(.615)$ & $(.144)$ & $(.109)$ \\
\hline Task & -.128 & 1 & .130 & -.142 & -.015 & -.016 \\
\hline & $(.398)$ & & $(.316)$ & $(.271)$ & $. .907)$ & $(.899)$ \\
\hline Time & $.375\left(^{* *}\right)$ & .057 & 1 & -.013 & .009 & $.250\left(^{*}\right)$ \\
\hline & $(.010)$ & $(.706)$ & & $(.920)$ & $(.945)$ & $(.050)$ \\
\hline Help & .177 & -.010 & -.007 & 1 & .011 & -.214 \\
\hline & $(.241)$ & $(.946)$ & $(.961)$ & & $.931)$ & $(.095)$ \\
\hline Peer & .185 & -.279 & $(-.030)$ & -.185 & 1 & -.055 \\
\hline & $(.219)$ & $(.061)$ & .842 & $. .220)$ & & .671 \\
\hline Final mark & $.309\left(^{*}\right)$ & -.007 & .188 & $.336\left(^{*}\right)$ & $.296\left(^{*}\right)$ & 1 \\
\hline & $(.037)$ & $(.961)$ & $(.211)$ & .022 & .046 & \\
\hline
\end{tabular}

Source: Own elaboration. Business and Administration (above the diagonal) and Economics (below the diagonal).

Table A3. Correlations by degrees: Accounting and Finance and Labour Relations and Human Resources

\begin{tabular}{|c|c|c|c|c|c|c|}
\hline & Performance & Task & Time & Help & Peer & Final mark \\
\hline \multirow[t]{2}{*}{ Performance } & 1 & $-.391\left(^{*}\right)$ & $.405\left(^{*}\right)$ & -.050 & .098 & $.442\left(^{*}\right)$ \\
\hline & & (.040) & (.033) & $(.800)$ & $(.621)$ & $(.018)$ \\
\hline \multirow[t]{2}{*}{ Task } & .025 & 1 & $-.398\left(^{*}\right)$ & .316 & -.249 & .129 \\
\hline & (.892) & & (.036) & $(.101)$ & (.202) & $(.512)$ \\
\hline \multirow[t]{2}{*}{ Time } & .178 & $\left..512^{(* *}\right)$ & 1 & .021 & .079 & .155 \\
\hline & $(.329)$ & $(.003)$ & & $(.916)$ & $(.691)$ & $(.431)$ \\
\hline \multirow[t]{2}{*}{ Help } & .235 & $.413\left(^{*}\right)$ & .021 & 1 & .136 & -.010 \\
\hline & $(.195)$ & (.019) & (.909) & & $(.490)$ & $(.958)$ \\
\hline \multirow[t]{2}{*}{ Peer } & .059 & -.083 & -.102 & .106 & 1 & .206 \\
\hline & $(.747)$ & (.651) & (.578) & $(.565)$ & & $(.292)$ \\
\hline \multirow[t]{2}{*}{ Final mark } & -.124 & .071 & .165 & -.095 & .196 & 1 \\
\hline & $(.500)$ & (.700) & (.367) & (.605) & (.282) & \\
\hline
\end{tabular}

Source: Own elaboration. Accounting and Finance (above the diagonal) and Labour Relations and Human Resources (below the diagonal).

\section{REFERENCE LIST}

Alonso Tapia, J. (1999). ¿Qué podemos hacer los profesores universitarios por mejorar el interés y el esfuerzo de nuestros alumnos por aprender?. in Premios nacionales de investigación e innovación educativa 1998, pp. 161-187, Ministerio de Educación y Cultura, Madrid,.

Auzmendi, E. (1992). Las Actitudes Hacia la Matemática-Estadística en las Enseñanzas Medias y Universitarias. Mensajero, Bilbao, España.

Baeten, M., Kyndt, E., Struyven, K., Dochy, F. (2010). Using student-centred learning environments to stimulate deep approaches to learning: Factors encouraging or discouraging their effectiveness. Educational Research Review, 5, 3, 243-260.

Blanco, A. (2008). Una revisión crítica de la investigación sobre las actitudes de los estudiantes universitarios hacia la estadística. Revista Complutense de Educación, vol 19, 2, 311-320.

Bond, M. E., Perkins, S. N., Ramirez, C. (2012). Students' perceptions of statistics: An exploration of attitudes, conceptualizations, and content knowledge of statistics. Statistics Education Research Journal, 11 (1), 6-25. 
Carmona, J. (2004). Una revisión de las evidencias de fiabilidad y validez de los cuestionarios de actitudes y ansiedad hacia la estadística. Statistics Education Research Journal, vol. 3, 1, 5-28.

Chang, L. (1996). Quantitative attitudes questionnaire: instrument development and validation. Educational and Psychological Measurement, vol. 56, 6, 1037-1042.

Chiesi, F., Primi, C. (2009). Assessing statistics attitudes among college students: Psychometric properties of the Italian version of the Survey of Attitudes Toward Statistics (SATS). Learning and Individual Differences, vol. 19, 2, 309-313.

Covington, M. (2000). Goal theory, motivation and school achievement: an integrative review. Annual Review of Psychoogy, vol. 51, pp.171-200.

Eichler, A., Zapata-Cardona, L. (2016). Empirical Research in Statistics Education, Part of the series ICME13 Topical Surveys, Springer International Publishing.

Estrada, A., Batanero, C., Fortuny, J. M. (2004). Un estudio comparado de las actitudes hacia la estadística en profesores en formación y en ejercicio. Enseñanza de las Ciencias, vol. 22, 2, 263-274.

García-Santillán, A., Escalera-Chávez, M., Rojas-Kramer, C., Córdoba-Rangel, A., Pozos-Texon, F. (2016). Students'attitudes toward statistics: a comparison between universities. The Online Journal of New Horizons in Education, 6, 1, 136-150.

Hair, J.F. Jr., Anderson, R.E., Tatham, R.L., Black, W.C. (1998). Multivariate Data Analysis (5th Edition). Upper Saddle River, NJ: Prentice Hall,

McKeachie, W. J., Pintrich, P.R., Lin, Y., Smith, D. (1986). Teaching and learning in the college classroom: A review of the research literature. Ann Arbor, National Center for Research to Improve Postsecondary Teaching and Learning, University of Michigan.

Millar, A. M., \& White, B. J. G. (2014). How do attitudes change from one stats course to the next? In K. Makar, B. de Sousa, \& R. Gould (Eds.), Sustainability in Statistics Education. Proceedings of the Ninth International Conference on Teaching Statistics (ICOTS9), Flagstaff, Arizona, USA. Voorburg: International Association of Statistics Education. Available at: https://icots.info/9/proceedings/pdfs/ICOTS9 1F2 MILLAR.pdf

Miller, R. B., Behrens, J. T., Green, B. A., Newman, D. (2007). Goals and perceived ability: impact on student valuing, self-regulation and persistence. Contemporary Educational Psychology, vol.18, 2-18

Mondéjar, J.,Vargas, M. (2010). Determinant factors of attitude towards quantitative subjects: differences between sexes. Teaching and Teacher Education, vol. 3, 26, 688-693

Mondéjar, J., Vargas, M., Bayot, A. (2008). Medición de la actitud hacia la estadística. Influencia en los procesos de estudio. Revista Electrónica de Investigación Psicoeducativa, vol. 3, 16, 729-748.

Pintrich, P., Smith, D., García, T., McKeachie, W. (1991). A manual for the use of the Motivated Strategies for Learning Questionnaire (MSLQ).National Center for Research to Improve Postsecondary Teaching and Learning. University of Michigan.

Pintrich, P.R., Smith, D.A.F., García, T., McKeachie, W.J. (1993). Reliability and predictive validity of the motivated strategies for learning questionnaire (MSLQ). Educational and Psychological Measurement, vol. 53, 801-803.

Pintrich, R. R., DeGroot, E. V. (1990). Motivational and self-regulated learning components of classroom academic performance. Journal of Educational Psychology, vol. 82, 33-40.

Rinaudo, C., Chiecher, A., Donolo, D. (2003). Motivación y uso de estrategias en estudiantes universitarios. Su evaluación a partir del Motivate Strategies Learning Questionnarie. Anales de Psicología, vol. 19, 107-119.

Roberts, D. M., Bilderback, E. W. (1980). Reliability and validity of a statistics attitude survey, Educational and Psychological Measurement, 40, 235-238

Roces, C., Tourón, J., Gonzáles-Torres, M. (1995). Motivación, estrategias de aprendizaje y rendimiento de los alumnos universitarios. Revista de Pedagogía, vol. 47, 107-120.

Schau, C., Emmioglu, E. (2012). Do introductory courses in the United States improve students' attitudes?. Statistics Education Research Journal, vol.11, 86-94.

Schau, C., Stevens, J., Dauphinee, T. L., Del Vecchio, A. (1995). The development and validation of the 
survey attitudes toward statistics. Educational and Psychological Measurement, vol. 5, 55, 868-875.

Shaughnessy, J. M. (2007). Research on statistics learning and reasoning. In F. K. Lester (Ed.), Second handbook of research on mathematics teaching and learning. A project of the National Council of Teachers of Mathematics (pp. 957-1009). Charlotte, NC: Information Age

Vanhoof, S., Castro-Sotos, A. E., Onghena, P., Verschafel, L., van Dooren, W., \& van den Noortgate, W. (2006). Attitudes toward statistics and their relationship with short- and long-term exam. Journal of Statistics Education, vol.14, 3. Available at: http://ww2.amstat.org/publications/ise/v14n3/vanhoof.html

Weinstein, C. (1987). Fostering learning autonomy through the use of learning strategies. Journal of Reading, vol. 30, 590-595.

Wise, S. L. (1985). The development and validation of a scale measurement attitudes toward statistics. Educational and Psychological Measurement, vol. 45, 401-405.

Zeidner, M. (1991). Statistics and mathematics anxiety in social science students: some interesting parallels. British Journal of Educational Psychology, vol. 61, 319-328. 